\title{
Karrataine Typography: A New approach to enhance communication.
}

\author{
Ibrahim Hassan \\ Lecturer Faculty of fine Arts, Department of Graphic design \\ Alexandria University, Egypt
}

\begin{abstract}
This paper introduces new kind of motion text called "Karrataine typography". This term describes a new type of motion typography. Karrataine is the word of Arabic origin, which means twice. Karrataine typography describes a case of movement where the character appears twice in different two image, the first image is the word structural form and the second image is a pictorial form which present the meaning of these word.

The main condition in the morphing from text to image is that the resulting image depends on the structural letterform of the word - meaning that the word and the graphic form meet in the same structural design.

Through an experiment conducted by the researcher, animated clips of the process of morphing the word into the expressed shape were shown to a number of persons of different ages. This is to measure how easy it is to recognize the shape and the word. Was the recipient able to connect them visually and mentally, or not?

Through the questionnaire, a comparison was made between the different ages without omitting the gender, so to know whether this method is effective with one age group without the other? Will the results differ according to the type? or not?
\end{abstract}

Keywords: karrataine typography, Fluid typography, Motion typography.

\section{INTRODUCTION}

Through the development of technology means and the booms that occurred to the communication channels, it became necessary to take advantage of the development of motions technology in the field of Visual communication - and to harness it to serve the Arabic language.

The main question in this paper is; As ancient writings like hieroglyphs, can a method be created to teach reading in a pictorial way? - without abandoning the idea of the alphabet? 


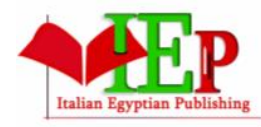

ISSN: $2735-4342$
INTERNATIONAL JOURNAL OF

MULTIDISCIPLINARY STUDIES IN ART AND

TECHNOLOGY

VOLUME 4, ISSUE 1, 2021, $443-456$.

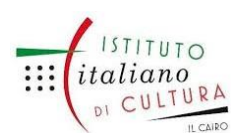

www.egyptfuture.org/ojs/

So that the reciever - child for example - can memorize the word form instead of the usual spelling? Can this have an effect on enhancing his cognitive abilities?

Based on these questions, thinking began to design a written word that carries a specific meaning, which is transformed visually to a pictorial form referring to the same meaning of the written word - and the researcher called that process "karrataine " inspired by that word from the word Quran in Surat Al-Molk. Then return the sight two balls "which means" look again "- in the works of" karrataine typography "is looked at for the first time to see the spelling word - then when look again we find it turned into a pictorial form that shows its meaning.

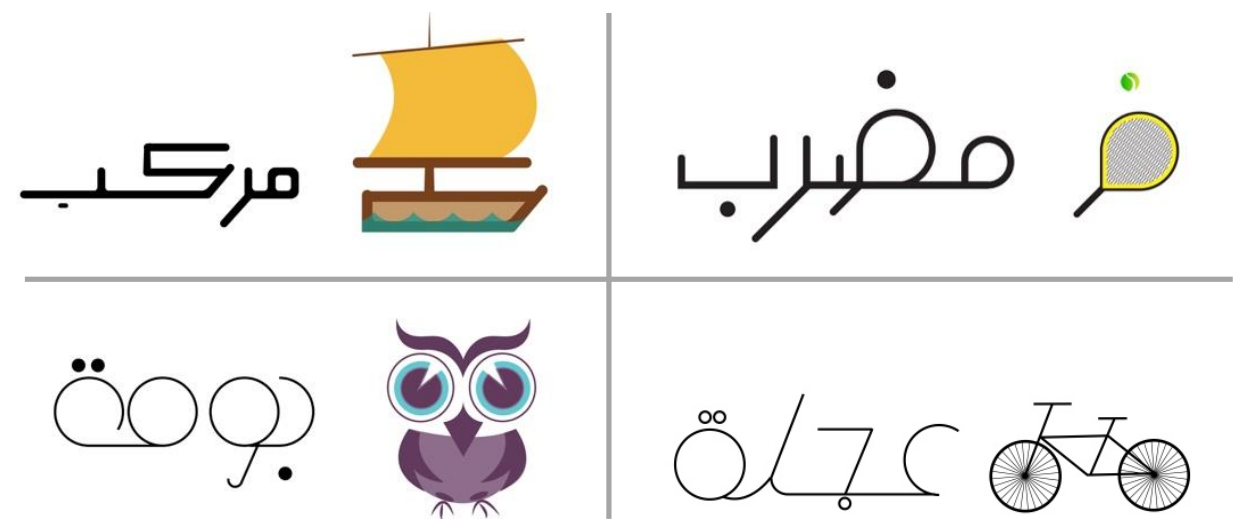

Fig.1

Same structure design - same meaning between word and pectorial sign

\section{Visual Sign CLASSIFICATION}

\section{Classification of pictorial signs:}

The pictorial signs was divided into 3 types: iconic signs, indixical signs, and symbolic signs. This common sign is distinguished through the realationship between signifier and signified.

Iconic signs: in which the relationship between the signifier and the signified is identical, for example using calculator sign to present the calculator tool.

The indexical signs: the relationship between the signifier and the signified is not identical, but the signifier relationship in expressing the signified is a direct relationship to it (as using Gears form to express the meaning of setting).

The symbolic sign: in the relation of the signifier and the signified relationship an arbitrary relationship.

Consider the concept of the sign within the field of visual communication. 


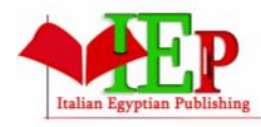

ISSN: 2735-4342

INTERNATIONAL JOURNAL OF

MULTIDISCIPLINARY STUDIES IN ART AND

TECHNOLOGY

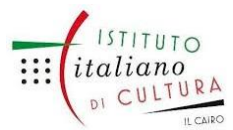

VOLUME 4, ISSUE 1, 2021, $443-456$.

www.egyptfuture.org/ojs/

So we find the iconic signs are writing depictions that are used to convey the meaning identical to what they denote. for example, using calculator sign to present the calculator tool.

indexical signs are used in the context of visual communication - such as using the shape of the brain's skull to express death or danger.

Symbolic signs are used in an abstract way that is not related to what they denote. People simply used a certain meaning when seeing them, for example: symbols of alphabetical writing.

\section{FROM TEXT TO IMAGE}

Edward kack addressed the talk about Fluid Typography that the structure of the letters does not have a fixed form, so it can be morphed and changed to give different identities without adding new shapes.[10], [4], [1]

While Hilner spoke about the concept of Temporal Typography, which is the text that appears gradually during a specific time, so that the text appears in a dynamic way, in which the reading process is slow due to the graphic shifts through time. [5], [4]

Hilner also addressed the talk about Virtual Typography, which deals with typographic solutions during a period of time in which there is a change in the nature of the information. The matter is not only dependent on a change in the spatial arrangements of the texts, but the Typographic elements develop directly from the image. [5]

Many researchers have concerned with how to use the energy of kinetic typography in conveying emotions and psychological expressions by relying on the metaphorical properties of the typefacees such as the size, shape and color of the letter as well as the effects and movement methods that enhance the communicative aspect of the expressive and psychological aspects. [7], [8], [9], [12]

\section{RESEARCH METHODOLOGY}

1- Design a specific Typeface, for specific word, which has its own structure and form. The word structure was used to extract a pictorial form from the same elements of the letterform structure. As shown in the following figures 
INTERNATIONAL JOURNAL OF

MULTIDISCIPLINARY STUDIES IN ART AND

TECHNOLOGY
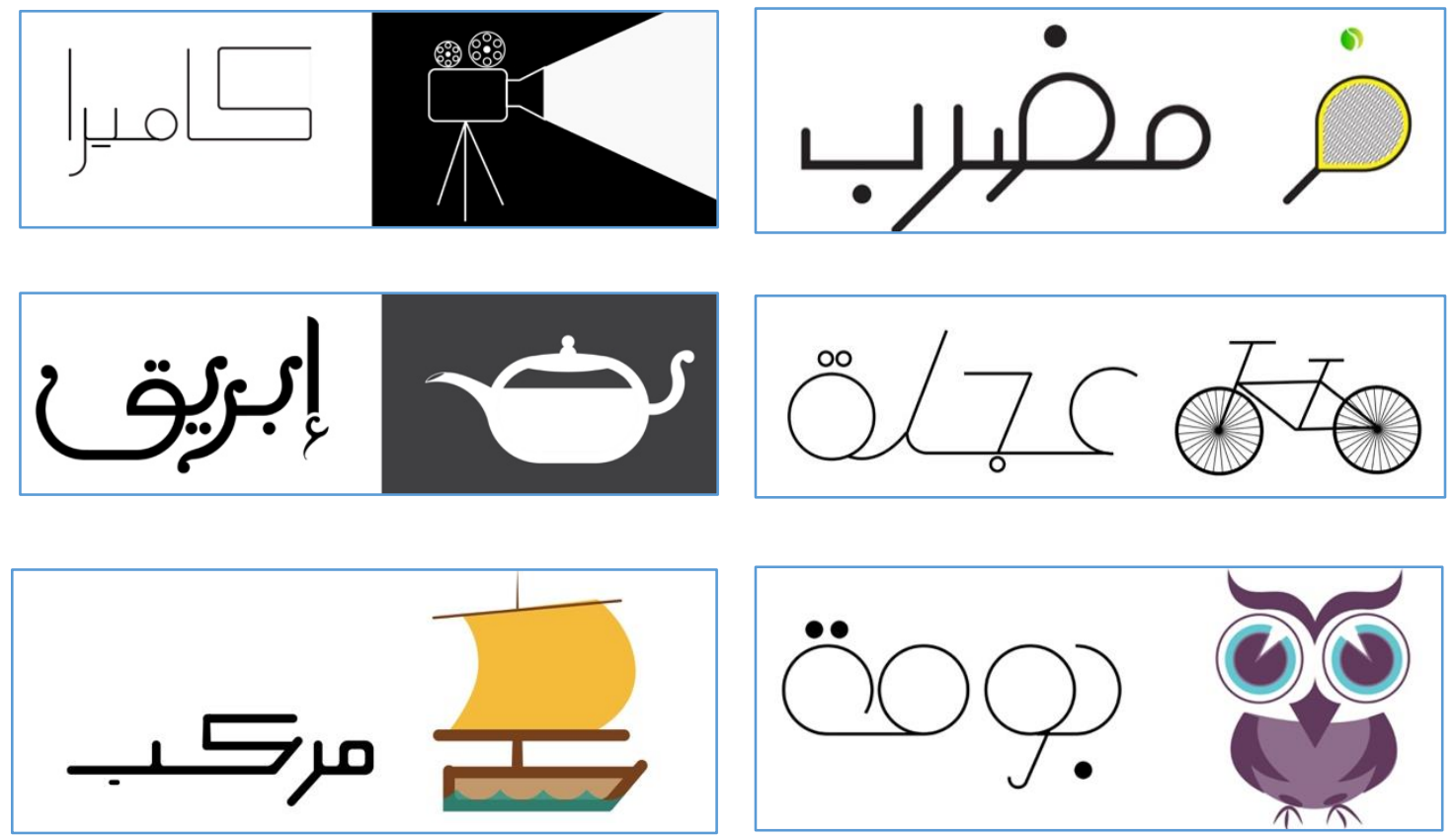

Fig. 2

It shows the designs that the questionnaire was made on.

2- the process of morphing from the word to the image have been designed through period of time - gif image.

3- The moving gif shown the process of transforming the word to the pectorial shapes which express its meaning.

4- Five (5) different Typefaces for the same word are presented to the people including the original word that is displayed in the gif image.

Does the people can distinguish the original typeface from the others? or not? How long does they take to distinguish that Typeface from others?

figure

showing the display of 5 words during the questionnaire, including the original used word, which the receiver should distinguish between 4 other forms of characters.
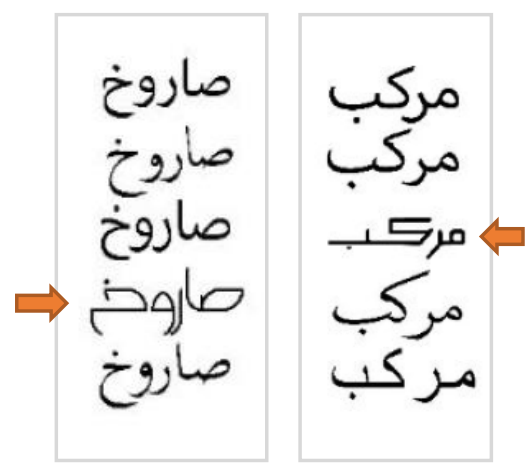
INTERNATIONAL JOURNAL OF

MULTIDISCIPLINARY STUDIES IN ART AND

TECHNOLOGY

VOLUME 4, ISSUE 1, 2021, 443 - 456.

www.egyptfuture.org/ojs/

It should be noted here that during the stages of the questionnaire, the researcher did not rely on the adoption of specific fonts for comparison in each questionnaire, but it was randomly.
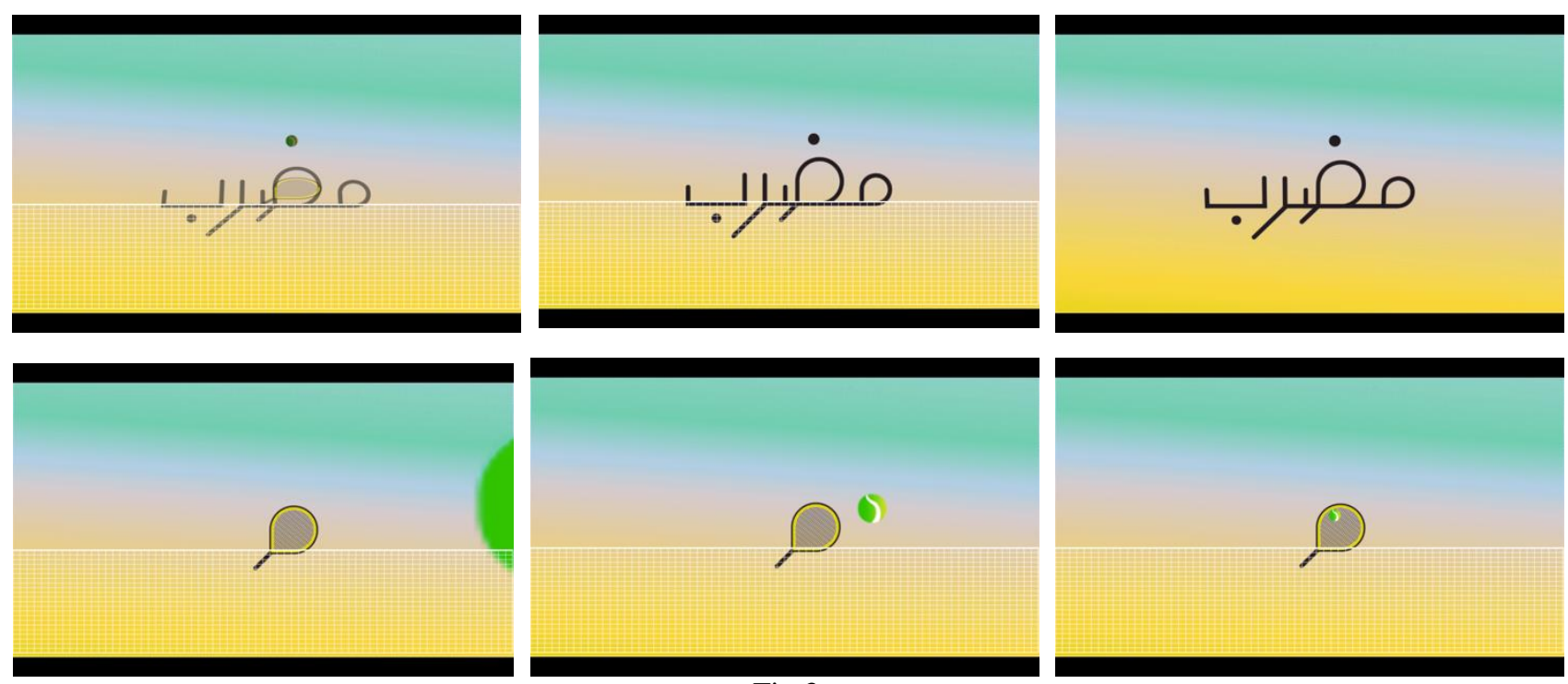

Fig.3

showing sequential images of showing the transition and transformation of the word - racket - " مضرب" to pictorial one.
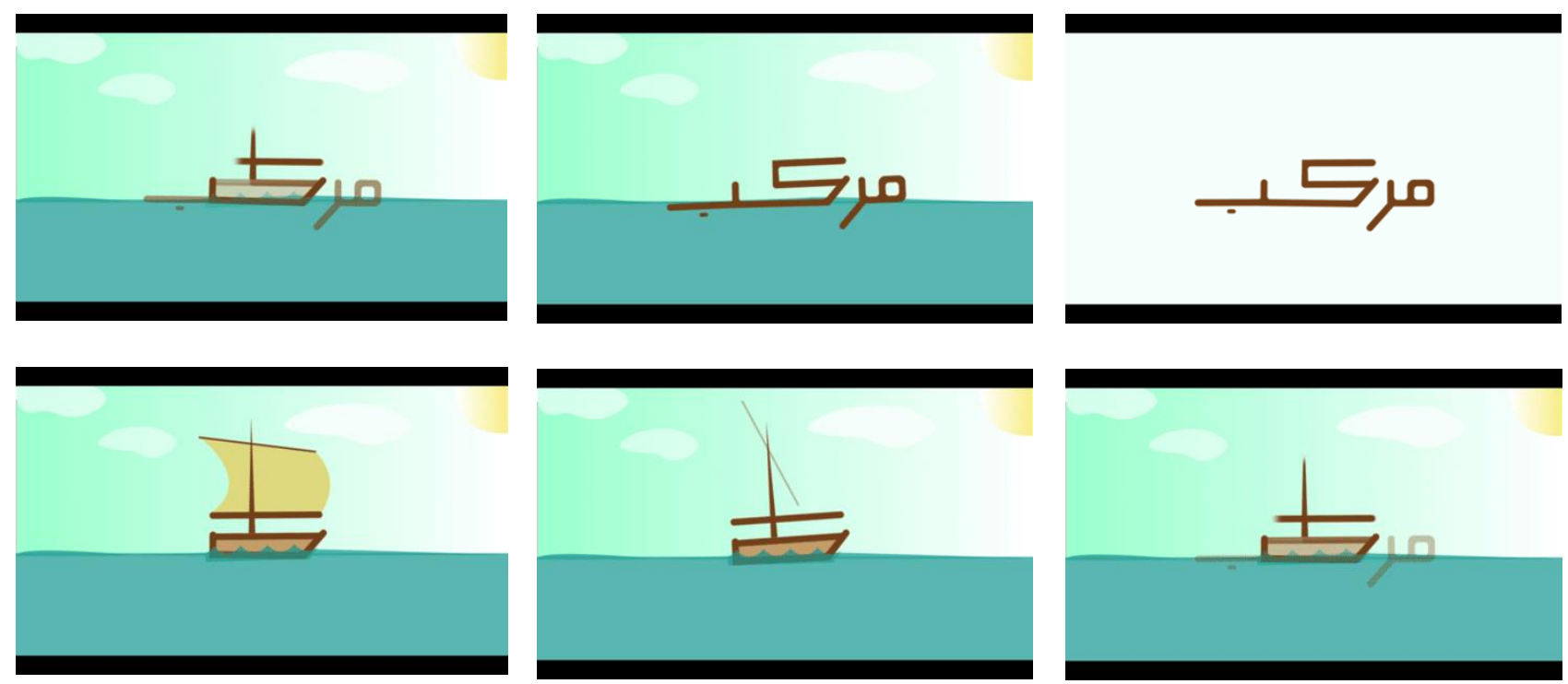

Fig.4

showing sequential images of showing the transition and transformation of the word - ship- "مركب" to pictorial one. 
INTERNATIONAL JOURNAL OF

MULTIDISCIPLINARY STUDIES IN ART AND

TECHNOLOGY

ISSN: $2735-4342$

VOLUME 4, ISSUE 1, 2021, 443 - 456.

www.egyptfuture.org/ojs/
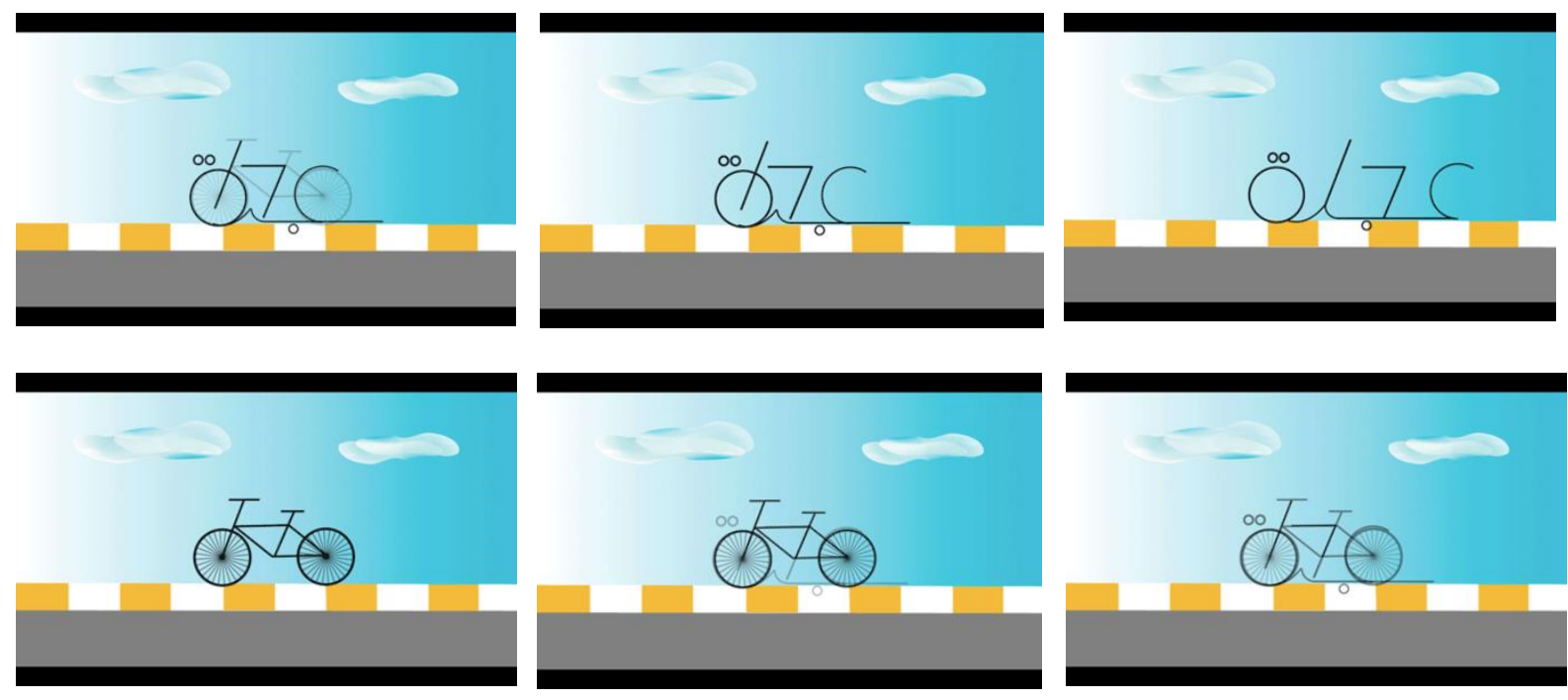

Fig.5

showing sequential images of showing the transition and transformation of the word - cycle- " عجلة to pictorial one.
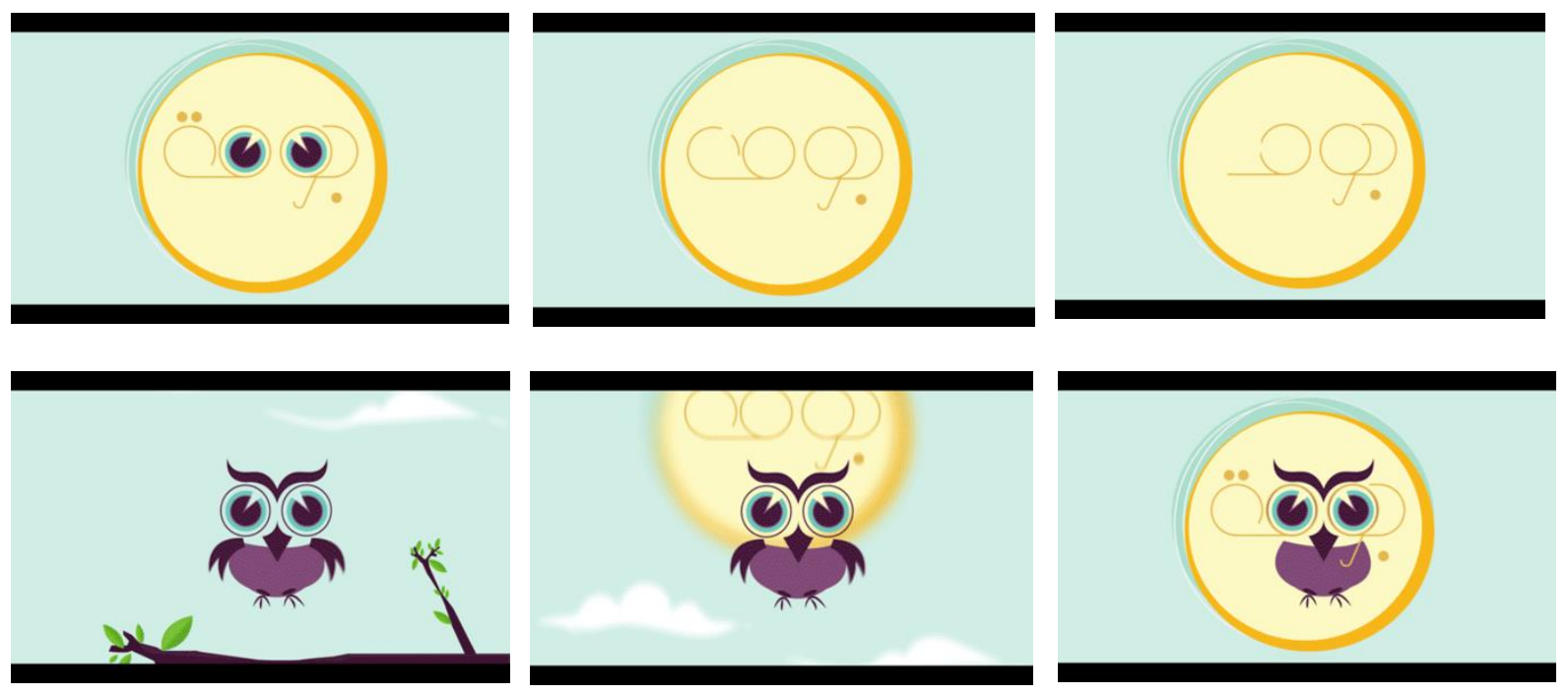

Fig.6

showing sequential images of showing the transition and transformation of the word - Owle- "بومة" to pictorial one. 
INTERNATIONAL JOURNAL OF

MULTIDISCIPLINARY STUDIES IN ART AND

TECHNOLOGY
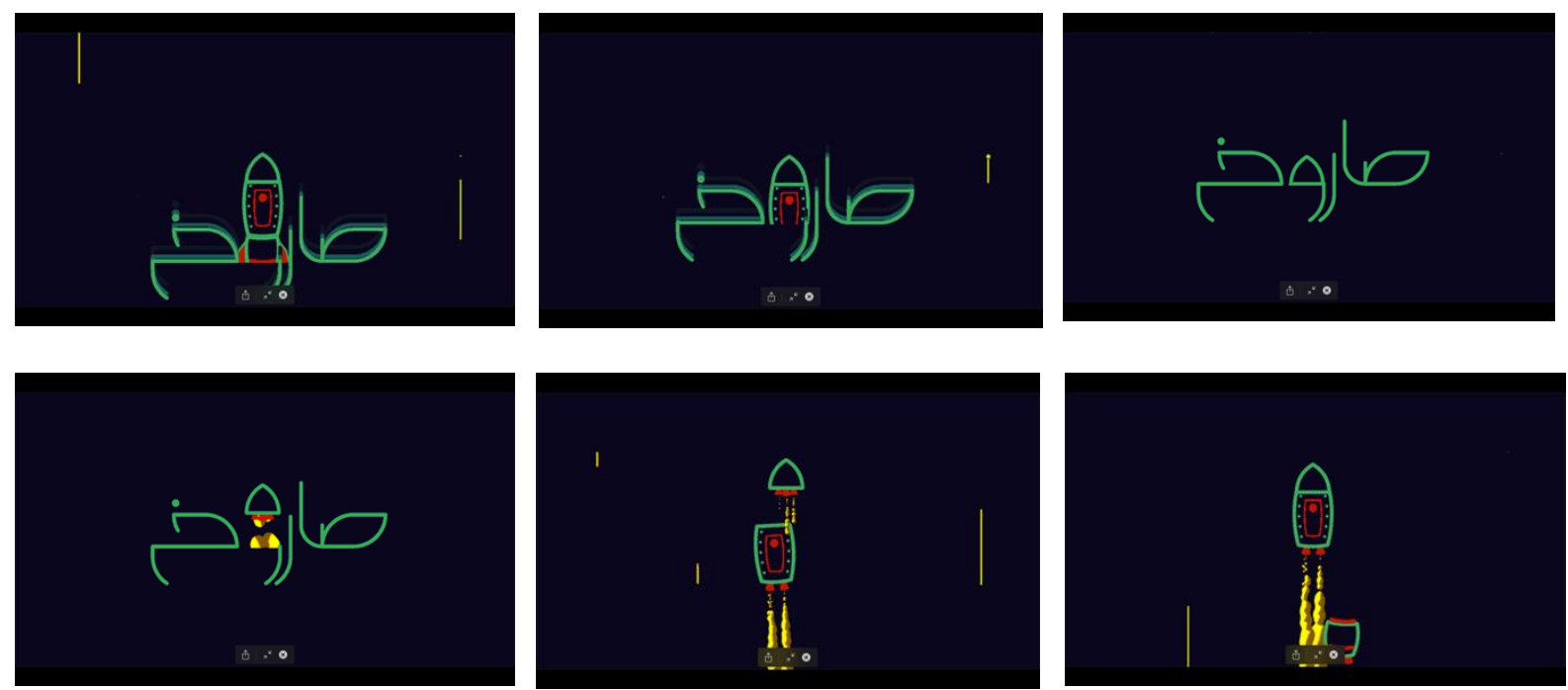

Fig.7

showing sequential images of showing the transition and transformation of the word - Rocket "صاروخ"- to pictorial one. 


\section{ANALYSIS OF RESULTS}

\section{Statistical analysis}

This new type of Typography was examined among different age groups and different gender. subjects were categorized according to age into four different groups

Group A: $<12$

Group B: 12-21

Group C: 22-40

Group D: 41-60

Statistical analysis was done using SPSS v.24. In case of comparing groups of continuous data, non-parametric Tests were used because of the violation of the parametric tests assumptions; Kruskal-Wallis test was used when comparing more than two variables and Mann-Whitney Test for two variables. Comparing groups of categorical data were done using chi-square test or Fisher's exact Test when estimated count of a cell is less than 5.

Four hundred and twenty subjects were studied and they were divided into 7 groups and the timing needed for readability were examined for words in table one.

The distribution of gender and age group among each word were nearly the same and no statistical difference as shown in table 2 and 3 and this indicates the homogeneity of different word samples.

then, different words checked that these word themselves did not affect the readability as shown in table 1 where there were no statistical difference in timing among word groups.

Timing differs significantly among ages categories as shown in table 4 where younger people took less time in word recognition as shown in fig 1. Concerning gender, there were no significant difference between males and females as shown in table 5.

finally, the interaction between gender and age and their effect on timing were studied were both genders in the youngest group had the same timing where males in the next two age categories had timing less than female whereas in the oldest age group the timing of females was less than males. However, the interaction effect was not statistically significant. Fig 2 


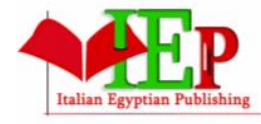

ISSN: $2735-4342$

INTERNATIONAL JOURNAL OF

MULTIDISCIPLINARY STUDIES IN ART AND

TECHNOLOGY

VOLUME 4, ISSUE 1, 2021, 443 - 456.

www.egyptfuture.org/ojs/

Table 1: Frequency of individuals at each word group:

\begin{tabular}{|c|c|c|c|c|}
\hline Group & Word & Frequency & $\begin{array}{l}\text { Timing(Mean } \pm S \\
\text { E) }\end{array}$ & Sig \\
\hline I & مضرب & 58 & $5.87 \pm 0.70$ & \multirow[t]{7}{*}{0.626} \\
\hline II & إبريق & 62 & $4.87 \pm 0.49$ & \\
\hline III & تلسكوب & 61 & $6.59 \pm 0.94$ & \\
\hline IV & بومة & 61 & $5.78 \pm 0.75$ & \\
\hline $\mathrm{V}$ & مركب & 61 & $4.86 \pm 0.55$ & \\
\hline VI & كامير ا & 60 & $4.52 \pm 0.49$ & \\
\hline VII & عجلة & 59 & $6.48 \pm 1.06$ & \\
\hline
\end{tabular}

Table 2: Distribution of gender among different word groups

\begin{tabular}{|c|c|c|c|}
\hline Word & Male & Female & sig \\
\hline مضرب & $30(11.9 \%)$ & $28(11.9 \%)$ & \multirow{7}{*}{$0.56^{\mathrm{C}}$} \\
\hline إبريق & $28(15.1 \%)$ & $34(14.4 \%)$ & \\
\hline تلسكوب & $21(11.3 \%)$ & $40(16.9 \%)$ & \\
\hline بومة & $25(13.4 \%)$ & $36(15.3 \%)$ & \\
\hline مركب & $27(14.5 \%)$ & $34(14.4 \%)$ & \\
\hline كامير ا & $30(16.1 \%)$ & $30(12.7 \%)$ & \\
\hline عجلة & $25(13.4 \%)$ & $34(14.4 \%)$ & \\
\hline
\end{tabular}

Table 3: Distribution of age categories among different word groups

\begin{tabular}{|c|c|c|c|c|c|}
\hline Word & $\mathrm{A}$ & B & $\mathrm{C}$ & $\mathrm{D}$ & sig \\
\hline مضرب & $11(15.5 \%)$ & $37(13.2 \%)$ & $7(11.7 \%)$ & $3(27.3 \%)$ & \multirow{7}{*}{$0.99^{\mathrm{F}}$} \\
\hline إبريق & $9(12.7 \%)$ & $42(15.0 \%)$ & $10(16.7 \%)$ & $1(9.1 \%)$ & \\
\hline تلسكوب & $6(8.5 \%)$ & $42(15.0 \%)$ & $12(20.0 \%)$ & $1(9.1 \%)$ & \\
\hline بومة & $11(15.5 \%)$ & $40(14.3 \%)$ & $9(15.0 \%)$ & $1(9.1 \%)$ & \\
\hline مركب & $12(16.9 \%)$ & $39(13.9 \%)$ & $9(15.0 \%)$ & $1(9.1 \%)$ & \\
\hline كامير ا & $10(14.1 \%)$ & $40(14.3 \%)$ & $7(11.7 \%)$ & $3(27.3 \%)$ & \\
\hline عجلة & $12(16.9 \%)$ & $40(14.3 \%)$ & $6(10.0 \%)$ & $1(9.1 \%)$ & \\
\hline
\end{tabular}




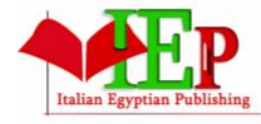

ISSN: $2735-4342$

INTERNATIONAL JOURNAL OF

MULTIDISCIPLINARY STUDIES IN ART AND

TECHNOLOGY

VOLUME 4, ISSUE 1, 2021, 443 - 456.

www.egyptfuture.org/ojs/

Table 4: Comparing timing between age categories:

\begin{tabular}{|c|c|c|c|}
\hline $\begin{array}{l}\text { Age } \\
\text { category }\end{array}$ & Frequency & $\begin{array}{l}\text { Timing(Me } \\
\text { an } \pm \text { SE) }\end{array}$ & Sig \\
\hline $\mathrm{A}$ & 71 & $2.87 \pm 0.18$ & \multirow{4}{*}{$<0.001$} \\
\hline $\mathrm{B}$ & 279 & $5.53 \pm 0.33$ & \\
\hline $\mathrm{C}$ & 60 & $7.52 \pm 0.91$ & \\
\hline $\mathrm{D}$ & 10 & $13.09 \pm 2.71$ & \\
\hline
\end{tabular}

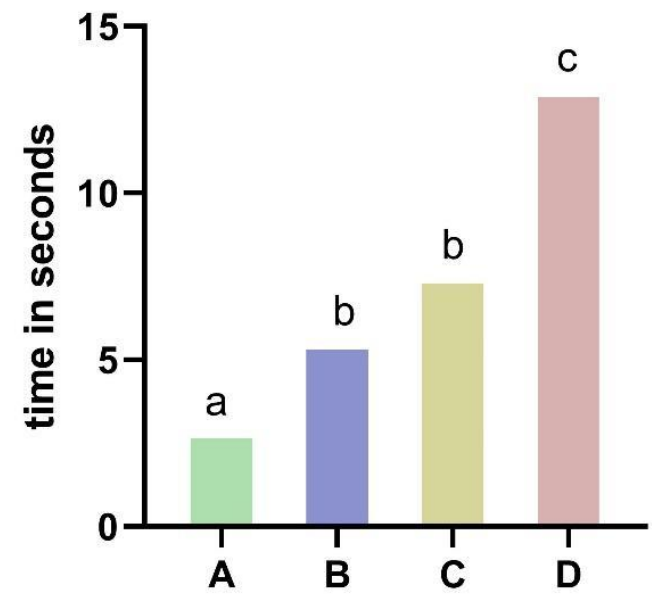

Age categories

Fig.9

showing that the age was directly proportional with timing

Table 5:Comparing timing between different genders:

\begin{tabular}{|l|l|l|l|}
\hline Gender & Frequency & $\begin{array}{l}\text { Timing(Me } \\
\text { an } \pm \text { SE })\end{array}$ & Sig \\
\hline Female & 235 & $5.561 \pm 0.38$ & 0.489 \\
\cline { 1 - 3 } Male & 185 & $5.563 \pm 0.40$ & \\
\hline
\end{tabular}




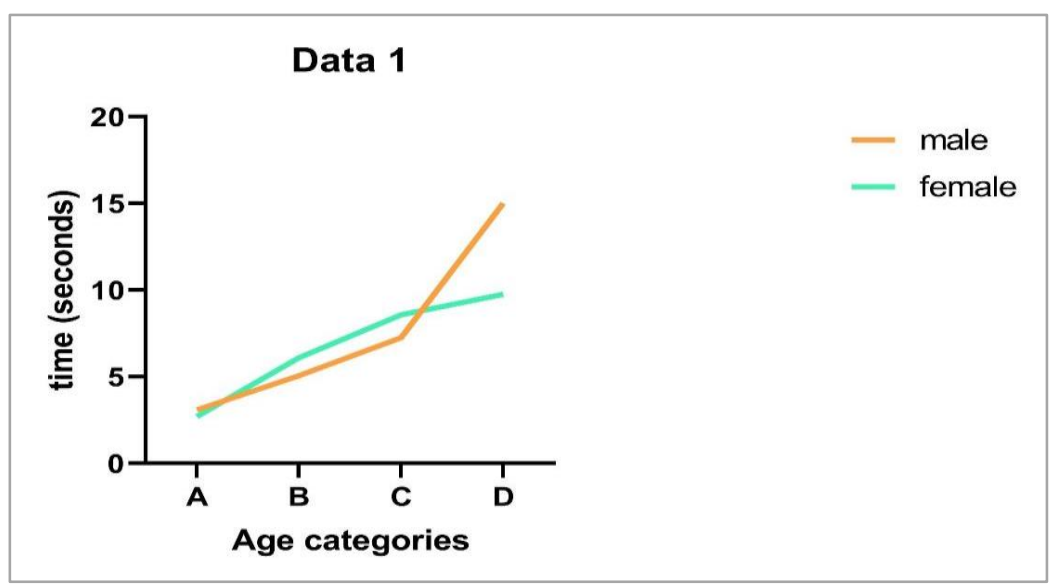

Fig.10

Showing the interaction between gender and age and their effect on timing

\section{DISCUSSION}

According to what was presented by Endsley Micach: A model for the basics of situational awareness is composed of three levels: The first level: awareness of elements in the environment, The second level: understanding the current situation. The third level: the projection or prediction of the future state, as in Fig. 11

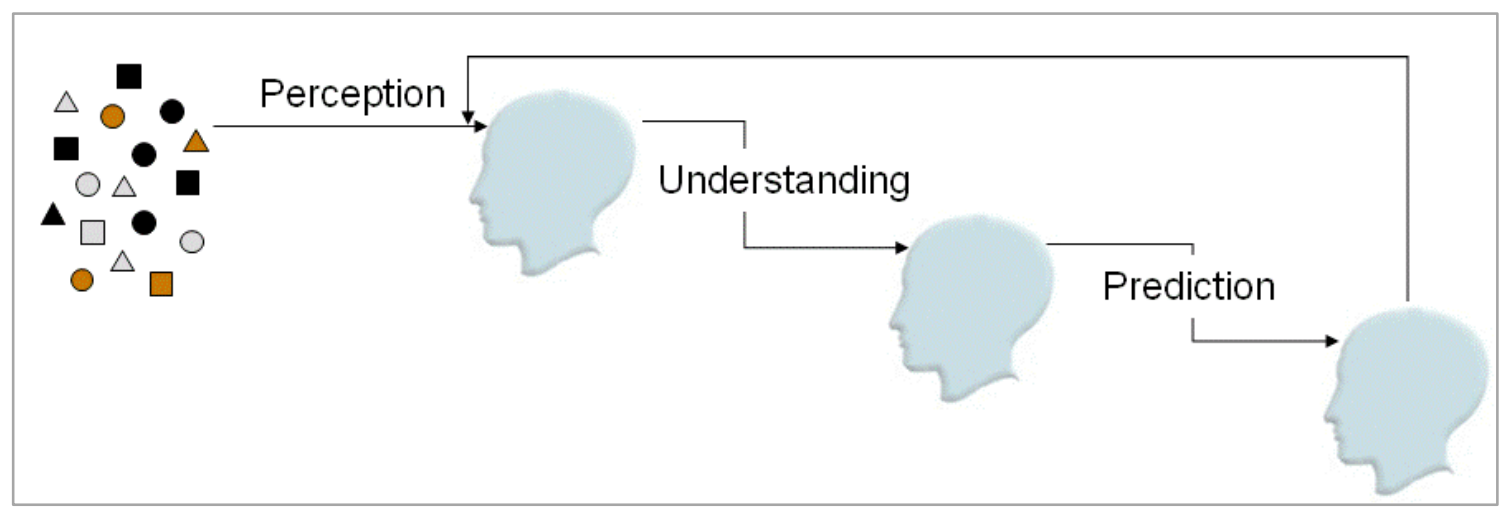

Fig. 11

Situational Awareness, Moodle by: Endsley Micach. [3]

According to Endsley Micach, the level of perception is the first step in achieving situational awareness. As for the perceptual aspect of the Karrataine typography, we find that at this level there is an interaction with long-term memory. While the information content is held in the 


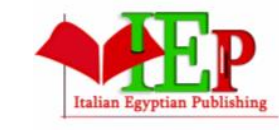

ISSN: $2735-4342$
INTERNATIONAL JOURNAL OF

MULTIDISCIPLINARY STUDIES IN ART AND

TECHNOLOGY

VOLUME 4, ISSUE 1, 2021, $443-456$.

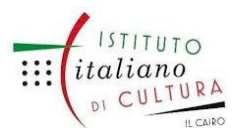

www.egyptfuture.org/ojs/

active working memory. As for the second level, the level of perception, we find it working to provide an organized state of the elements with an understanding of the importance of things and events. [2], [3], [11]

This can be confirmed through the unified structure between form and word in Karrataine typography, and this level with regard to the perceptual aspect, we find that the mental models stored in the long-term memory are considered the main durations of the second level of situational awareness.

If the recipient is not proficient in reading, then he will rely heavily on the pictorial form, and if he is fluent in reading, he will neglect the pictorial aspect and focus more on spelling the word and forget its appearance, and this seems to be the scientific reason that made the results of word extraction in young people better to be able to link the structure to the pictorial form stuck in Their minds.

Projection level enables predictions about the state of the environment in the near future. This is achieved by knowing the state and dynamics of the elements, which helps in understanding and understanding the situation. Here comes the role of the movement in confirming the unified structural structure to assist in the prediction process and the ability in the future to be able to preserve the shape of the word and link it mentally to the image that was presented.

\section{CONCLUSION}

The energy of Karrataine typography can be used in the educational process, especially in teaching reading to children or beginners in learning.

The effect of the age stage appeared clearly in the time required to recognize the word, as the lower the age, the less time the recognition was, and perhaps this is due to the fact that the child in the first age stages depends on distinguishing words through their form rather than through reading them - especially in the early stages And that is where his reading ability has not matured yet, as his mental model has not completed the ability to spell, but rather depends on the experiences resulting from the visual inventory with his temporary memory to a large extent. As for the elderly, his mental side is stronger and often depends on the experiences resulting from his long memory and what is the term in arranging the places of the letters and the ability to spell and form words. 


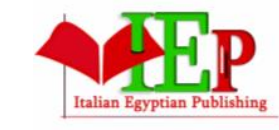

ISSN: $2735-4342$

\section{INTERNATIONAL JOURNAL OF \\ MULTIDISCIPLINARY STUDIES IN ART AND \\ TECHNOLOGY}

VOLUME 4, ISSUE 1, 2021, $443-456$.

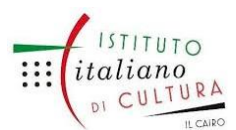

www.egyptfuture.org/ojs/

1. Karrataine typography showed a great ability to distinguish characters.

2. Young ages have a great ability to link the letter form with the pictorial shape, which have the same structure.

3. The gender factor was not considered at young ages But it became clear as the age was older, so there appeared to be a difference in the results in the female superiority of men in the speed of distinguishing words.

4. Statistical analyzes showed that there was no clear difference between males and females at young ages, and therefore we recommend using them for the educational purpose in schools. It is not preferable to use this method at older ages, because it takes a long time to perceive.

5. Some of the words took a long time to distinguish because the typographical design was intricate like the word. "نلسكوب" telescope.

6. Some words need a long time to distinguish because the typographical design was not distinct enough from the words displayed, like the word "كامير " camera.

\section{REFERENCES}

1.Brownie, B. (2007 ). One Form, Many Letters:Fluid and transient letterforms in screenbased typographic artefacts . the MeCCSA Postgraduate Network Conference.

2. Chrysoula Gatsou, Anastasios Politis, Dimitrios Zevgolis. "THE IMPORTANCE OF MOBILE INTERFACE ICONS ON USER INTERACTION." International Journal of Computer Science and Applications 9.3 (2012): 92 - 107.

3. FL Greitzer, CF Noonan, LR Franklin. Cognitive Foundations for Visual Analytics. U.S. Department of Energy . USA: Pacific Northwest national laboratory, 2011. 
INTERNATIONAL JOURNAL OF

MULTIDISCIPLINARY STUDIES IN ART AND

TECHNOLOGY

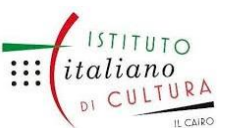

ISSN: 2735-4342

VOLUME 4, ISSUE 1, 2021, $443-456$.

www.egyptfuture.org/ojs/

4. hassan, I. (2013). Motion Effects Of Arabic Typography In Digital Communication Media,Faculty Of Fine Arts, Alexandria University, Department of Graphic design. Egypt: Un Puplished.

5. Hillner, M. (2009 ). Virtual typography, AVA Publishing, United Kingdom.

6. Hostetler, S. C. (2006). Integrating Typography and Motion in Visual Communication. iDMAa and IMS conference. Miami.

7. Jun, S. (2000). The New Typography Today. Master Thesis, Carnegie Mellon University, Interaction Design.

8. Johnny C. Lee, J. F. (2002). The Kinetic Typography Engine: An Extensible System for Animating Expressive Text. UIST '02 Symposium on User Interface Software and Technology. Paris, France.

9. Joonhwan Lee, S. J. (2006, June 26-28). Using Kinetic Typography to Convoy Emotion in Text-Based interpersonal Communication.

10. Kac, E. (2007). Media Poetry:An International Anthology, Intellect Books, USA

11. MR Endsley , Situation awareness, - Handbook of human factors and ergonomics vol.3, pp 528-542, Wiley, 2006.

12. Uekita, Y. H. (1995). The possibility of kinetic typography expression in the. Internet art museum. IEEE SMC99 (pp. 230-235). Ullmer. 